
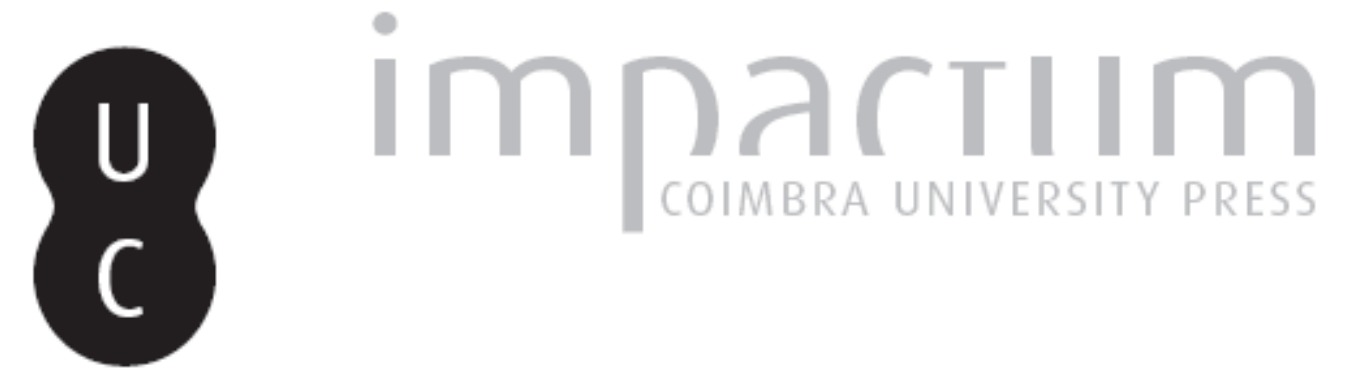

\title{
Does Aristotle have a dialectical attitude in EE I 6: a negative answer
}

Autor(es): $\quad$ Mendonça, Fernando $\mathrm{M}$.

Publicado por: Annablume Clássica; Imprensa da Universidade de Coimbra

URL persistente:

URI:http://hdl.handle.net/10316.2/41603

DOI:

DOI:https://doi.org/10.14195/1984-249X_20_7

Accessed : $\quad$ 26-Apr-2023 14:27:32

A navegação consulta e descarregamento dos títulos inseridos nas Bibliotecas Digitais UC Digitalis, UC Pombalina e UC Impactum, pressupõem a aceitação plena e sem reservas dos Termos e Condições de Uso destas Bibliotecas Digitais, disponíveis em https://digitalis.uc.pt/pt-pt/termos.

Conforme exposto nos referidos Termos e Condições de Uso, o descarregamento de títulos de acesso restrito requer uma licença válida de autorização devendo o utilizador aceder ao(s) documento(s) a partir de um endereço de IP da instituição detentora da supramencionada licença.

Ao utilizador é apenas permitido o descarregamento para uso pessoal, pelo que o emprego do(s) título(s) descarregado(s) para outro fim, designadamente comercial, carece de autorização do respetivo autor ou editor da obra.

Na medida em que todas as obras da UC Digitalis se encontram protegidas pelo Código do Direito de Autor e Direitos Conexos e demais legislação aplicável, toda a cópia, parcial ou total, deste documento, nos casos em que é legalmente admitida, deverá conter ou fazer-se acompanhar por este aviso.

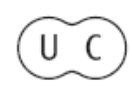




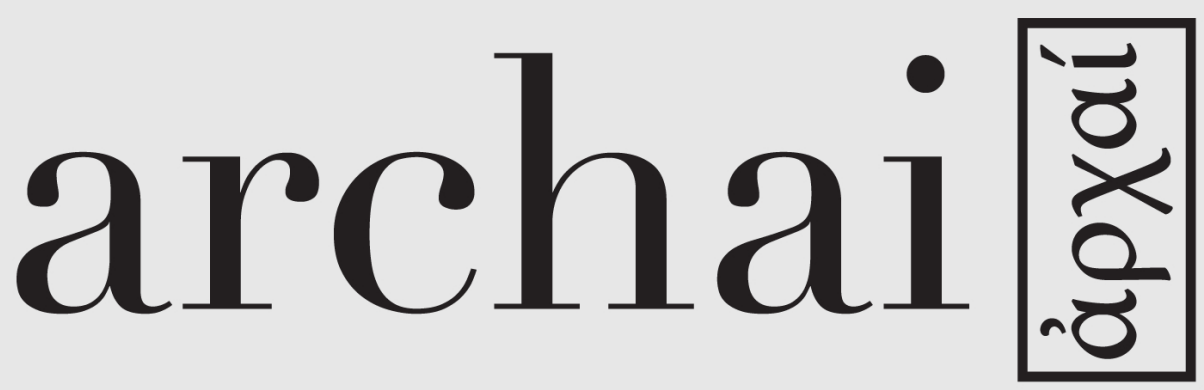

Revista sobre as origens do pensamento ocidental Journal on the Origins of Western Thought

20 | may-aug. 2017 


\title{
Does Aristotle have a diA- LECTICAL ATTITUDE IN EE I 6? A NEgATIVE ANSWER
}

MENDONÇA, Fernando M. (2017). Does Aristotle have a dialectical attitude in EE I 6? A negative answer. Archai, n. ${ }^{\circ} 20$, may-aug, p. 161-190 DOI: https://doi.org/10.14195/1984-249X_20_7

\begin{abstract}
In this paper, I analyse EE I 6, where Aristotle presented a famous methodological digression. Many interpreters have taken this chapter as advocating a dialectical procedure of enquiry. My claim is that Aristotle does not keep a dialectical attitude towards endoxa or phainomena in this chapter. In order to accomplish my goal, I shall show that EE I 6 does not provide enough evidence for the dialectical construal of it, and that this construal, in turn, hangs on some assumptions brought out from other Aristotelian works (EN and Top.), which do not provide good evidence either. By the examination of these assumptions, I intend to show that Aristotle is not carrying out any sort of dialectic, especially dialectic conceived as conceptual analysis seeking to save phainomena or endoxa.
\end{abstract}

Keywords: Dialectic, Causality, Endoxa, Phainomena.

archai圈

n 20, may-aug. 2017 


\section{archai圈}

no 20, may-aug. 2017

Fernando Mendonça, 'Does Aristotle have a dialectical attitude in EE I 6? A negative answer', p. 161-190

\section{INTRODUCTION}

In the last few decades, many scholars have proposed some sort of revival of Aristotle's dialectic ${ }^{1}$. This renewed interest in the Aristotelian dialectic placed the Topics as a work worth of close scrutiny, especially the first two chapters of book I, where Aristotle offers some details about the concept of endoxa and of dialectical syllogism. In Top. I $1^{2}$, Aristotle makes very clear that endoxa are used as premises of any dialectical syllogism. In spite of this clear statement on the endoxicality of dialectical premises, Top. I 1 is still vague and many ways of construing Aristotle's positions are possible. Some interpreters have understood that Top. I supplies Aristotelian philosophy a method of inquiry ${ }^{3}$ inasmuch as dialectic is an argumentative activity which proceeds from endoxa, and endoxa are presented along these lines: "Those [things] are acceptable [endoxa], on the other hand, which seem so to everyone, or to most people, or to the wise - to all of them, or to most, or to the most famous and esteemed." (Top. I 1 100b21-23) $)^{4}$ Endoxa are presented under a criterion that establishes them as opinions which everyone or some representative group of people are prone to accept. Now, if all it takes for an argument to be dialectical is to have endoxa as premises, all arguments Aristotle deploys using his predecessor philosophers' opinions or some reputable opinion widely shared are candidates to be dialectical arguments.

Considering this picture, some interpreters have been defending that dialectical arguments are spread all over Aristotle's works and that they are an important aspect of his philosophical enquiry. Nonetheless, it is not in the Topics where they find how dialectical 
enquiry is detailed. One very important text claimed to develop Aristotelian conception of dialectical enquiry is EE I 6 1216b26-35. In what follows, I shall present a dialectical construal of this text and then analyse the assumptions made by it. My claim is that a dialectical construal of this passage is not a viable one since it does not fit well in the context where it is located, and has no support of other important text held as elaborating on the dialectical enquiry in the clearest way, namely EN VII I 1045a2-75.

\section{A dialectical CONSTRUal of EE I 6 1216B26-35}

After presenting the overall purpose of the treatise and some common conceptions of happiness, Aristotle opens EE I 6 by detailing a sort of method to be followed in his enquiry. The text runs like this:

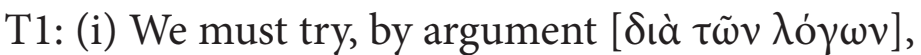
to reach a convincing conclusion on all these questions, (ii) using, as testimony and by way of example, what appears to be the case [ it would be best if everyone should turn out to agree

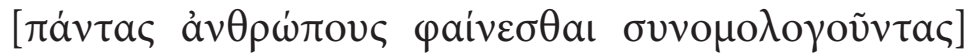
with what we are going to say; (iv) if not that, that they should all agree in a way and will agree after a

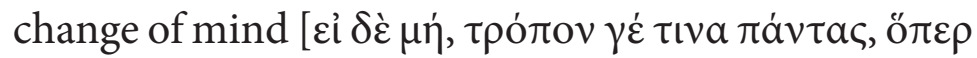

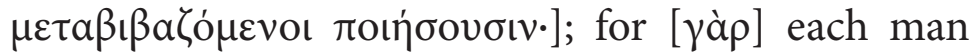
has something of his own to contribute to the finding of the truth, and it is from such (starting-points) that we must demonstrate ( $\delta \varepsilon \imath \kappa v v \dot{v a l})$ : (v) beginning with things that are correctly said, but not clearly, (ek gar tōn alēthōs men legomenōn ou saphōs de) as we proceed we shall come to express them clearly, with what is more perspicuous at each stage superseding what is

\section{archai圈}

no 20, may-aug. 2017

Fernando Mendonça, 'Does Aristotle have a dialectical attitude in EE I 6? A negative answer', p. 161-190 


\section{archai圈}

no 20, may-aug. 2017

Fernando Mendonça, 'Does Aristotle have a dialectical attitude in EE I 6? A negative answer', p. 161-190

\section{4}

customarily expressed in a confused fashion (EE I 6 1216 b 26-35) $)^{6}$.

The dialectical construal I am depicting here is strongly based on dialectic taken as conceptual analysis, in which proceeding by means of solving obscure language or poor formulation of endoxic propositions is the main feature of dialectical enquiry ${ }^{7}$. Nonetheless, most of my points target any sort of dialectical enquiry not confined within the limits of the regulated debate Aristotle describes in Topics VIII ${ }^{8}$.

Interpretations of this sort hang on several assumptions. By itself, EE does not supply dialectical interpreters all the evidence they need. There are, at least, five assumptions they need to import from different works to support their dialectical reading of $\mathrm{T} 1$.

\section{A1 - 'phainomena' means 'endoxa'}

The term 'endoxa' does not appear in T1 and this text does not make manifest that the term 'phainome$n a$ ' is interchangeable with 'endoxa'. Even if a dialectical interpreter does not concede the interchangeability salva veritate between 'phainomena' and 'endoxa', she will be willing to accept that some phainomena are endoxa $a^{9}$. In order to support her claim, the dialectical interpreter would take as her strongest evidence the very famous text from EN VII 1 1145b2-7:

T2: "As in other cases, we must set out what appears true

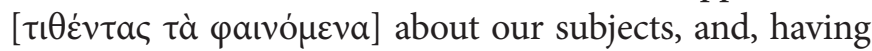

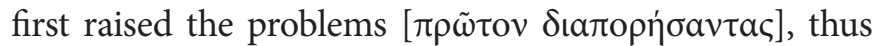
display, if we can, all the views people hold [ $\left.\varepsilon^{\prime} v \delta o \xi \alpha\right]$ about these ways of being affected, and if not, the larger part of 
them, and the most authoritative; for if one can both resolve the difficult issues about a subject and leave people's views on it undisturbed, it will have been clarified well enough." ${ }^{10}$

This passage has been interpreted as the most finegrained description of the dialectical procedure in Aristotle's works. Accordingly, dialectical method would consist of a three-step argumentative strategy. Firstly, the enquirer should stablish all the relevant phainomena regarding her subject matter. Next, she shall create aporiai from endoxa. Thirdly, she shall get 'good enough' proof if the examined endoxa rest undisturbed after the diaporia. The sequel of T2 (EN VII 1 1045b8-20) displays a number of opinions shared on akrasia saying that they are legomena, i.e., things said about akrasia. Owen's (1986, p.240) influential construal of this sequel of T2 claims that the legomena are the phainomena about akrasia. Instead of being empirical data, these phainomena are propositions held by a representative group of people or "conceptual structure revealed by language" (Owen, 1986, p.240). By being so, each of these phainomena is a legomenon that instantiates an endoxon, since endoxa are said to be what appear to everyone, or to most people, or to the wise. Thus, 'phainomena' in the first step of the method displayed in T2, and 'endoxa' in the following steps are taken as having the same referents. These terms refer to all the propositions enumerated in T2's sequel. Hence, a dialectical interpreter does not need to be committed to a salva veritate interchangeability between 'phainomena' and 'endoxa'; all she needs is that some phainomena instantiate endoxa, and that this occurs both in T1 and T2.

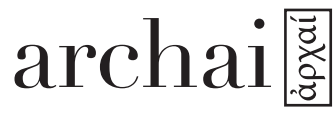

no 20, may-aug. 2017

Fernando Mendonça, 'Does Aristotle have a dialectical attitude in $E E$ I 6? A negative answer', p. 161-190 


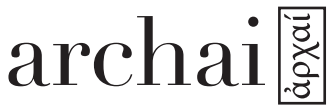

no 20, may-aug. 2017

Fernando Mendonça, 'Does Aristotle have a dialectical attitude in EE I 6? A negative answer', p. 161-190
This being said, the purportedly dialectical procedure of enquiry consists of, firstly, setting the relevant phainomena/endoxa. If there are inconsistencies within the set of relevant phainomena/endoxa, the enquirer needs, as the second step, to present these inconsistencies as aporiai. By means of some sort of conceptual analysis, it would be possible to sort out the inconsistencies and hopefully obtain 'good enough' proof, i.e., the consistency of the most authoritative phainomena/endoxa.

In T1's step (ii), Aristotle says that phainomena consisting of testimonies and examples are the means to reach conviction through argument, which is the goal step (i) seeks. Now, as EN VII 1, EE I 6 does not clearly refer to empirical data. Rather, in $\mathrm{T} 1$, propositions are what seem to be at stake, and that most men know at least part of the truth about happiness. Consequently, as T1 involves phainomena which seem to be endoxa (even if the term 'endoxa' is never used in it), dialectical interpreters can claim that T1 is a program for dialectical enquiry ${ }^{11}$.

\section{A2 - at least one 'endoxon' is at stake in $E E$ I 6}

If $E E$ I 6 sets a programme for dialectical enquiry, then it needs to refer to some endoxa. These endoxa are precisely the bearers of something true each man has of his own, as stated in T1 (iv). What endoxa do they refer to?

The answer to this question is not simple, though. Aristotle, in the course of his endeavour to reach a clear definition of eudaimonia, mentions some commonly shared opinions about what eudaimonia is or what it consists of. In EE I $31214 \mathrm{~b} 28-31$ he says that 
not all opinions count the same. Whilst everybody seems to find an easy task to say what eudaimonia is and what it consists of (I 5 1215b15-18), some people's opinion will not be taken under scrutiny, since they are clearly wrong.

The opinions Aristotle holds as relevant to his enquiry on happiness consider happiness the greatest possible human good and that it is constituted of either virtue, wisdom or pleasure, which respectively constitutes political life, philosophical life and life of enjoyment (EE I 1 1214a30-33, I 4 1215a32b-1) ${ }^{12}$. So, it is quite certain that there are some opinions held as relevant for Aristotle present in T1's context, and, thus, the dialectical interpreter is supplied with endoxa necessary to put the dialectical procedure at work.

\section{A3: 'endoxa' are the domain of dialectic and of dialectic only}

A dialectical reading of EE I 6 needs to identify 'phainomena' with 'endoxa' as shown in A1. This identification is a necessary condition for a dialectical reading of this text, but it is not a sufficient condition. Another important element compounding the dialectical reading is that endoxa are the domain of dialectic and dialectic only. This is needed because if endoxa were not the domain of dialectic only, one could not affirm that EE I 6 is dialectic without qualification. Thus, if there would be another branch of knowledge or method of enquiry that has endoxa as its domain, there would be some indeterminacy about which branch of knowledge or method of enquiry would deal with the endoxa mentioned in A3.

\section{archai蒡}

no 20, may-aug. 2017

Fernando Mendonça,

'Does Aristotle have a dialectical attitude in $E E$ I 6? A negative answer', p. 161-190 


\section{archai}

no 20, may-aug. 2017

Fernando Mendonça, 'Does Aristotle have a dialectical attitude in EE I 6? A negative answer', p. 161-190
In order to guarantee that endoxa are the domain of dialectic and dialectic only, one needs a much stronger claim that dialectical reasoning uses endoxa. One needs to be committed to a thesis according to which a reasoning is dialectical if and only if it uses endoxa. Now, evidence for this stronger claim is an Achilles's heel for such a dialectical interpreter.

Of course an alternative way to guarantee that phainomena in EE I 6 are endoxa, and that the methodology there deployed is dialectical, is possible. All one needs to show is that $E E \mathrm{I} 6$ advances a procedure backed by some evidence which clearly is identified as dialectic. The commonly deployed evidence, as pinpointed above, is EN VII $11145 \mathrm{~b} 2-7$, which, in turn, depends on further evidence, since there is no clear mention in its context that it is dialectical. Again, the claim that this $E N$ 's passage is proposing a dialectical procedure hangs on the assumption that the diaporia of endoxa is a sufficient condition to identify an argumentative procedure as dialectical, since it uses endoxa. If this is so, the dialectical interpreter is caught over again by the same trap.

To scape this trap, one might resort to the Top. I 2 101a34-b3, where Aristotle says that inasmuch dialectic more than anything else examines (exestatike ousa) endoxa about any subject. This is a more sophisticated move $^{13}$ and I shall present this in A4.

\section{A4: dialectic is a method of enquiry whose pro- cedure consists in the examination of endoxa.}

At the beginning of the Topics, Aristotle says that the goal of the treatise is to find a method which 
would enable one to argue from endoxa (Top. I 1 100a18-24) and that dialectical syllogisms have endoxa in its premises (Top. I 1 100a29-30). In addition to these passages, Aristotle affirms that the treatise is also useful for philosophical sciences inasmuch as it would make one more capable of proceed through aporiai and that dialectic promotes some sort of exam of endoxa more than anything else:

T3: It is useful in relation to the philosophical sciences because if we have the ability to go through the difficulties $(\delta\llcorner\alpha \pi \circ \rho \tilde{\eta} \sigma a \iota)$ on either side we shall more readily discern the true as well as the false in any subject.

Furthermore, it is useful in connection with the first of the starting-points about any individual science. For if we reason from the starting-points appropriate to the science in question, it is impossible to make any statement about these (since these starting-points are the first of them all), and it is by means of what is acceptable about

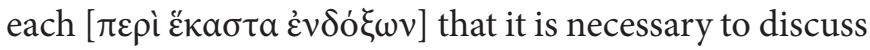
them. But this is unique, or at any rate most appropriate,

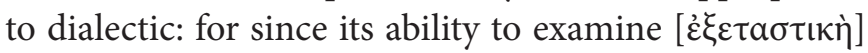
applies to the starting-points of all studies, it has a way to proceed. (Top. I 2 101a34-b3)

This apparent features of dialectic in the Topics must square the procedures described in T1 and T2. Thus, the exam referred to in T3 must somehow pick up the procedures the two ethical treatises describe. Furthermore, this exam must instantiate a kind of argument the Topics' opening paragraph affirms to be the goal it accounts for.

\section{archai蒡}

no 20, may-aug. 2017

Fernando Mendonça, 'Does Aristotle have a dialectical attitude in $E E$ I 6? A negative answer', p. 161-190 


\section{archai 䀥}

no 20, may-aug. 2017

Fernando Mendonça, 'Does Aristotle have a dialectical attitude in EE I 6? A negative answer', p. 161-190

\section{A5: dialectical method is prolific at least to the extent that it can produce agreement.}

This assumption is backed by the sentence introduced by the 'gar' in T1's line 31, which displays the reason why relevant people would agree with what is going to be said. What makes people agree with what they would not be willing to agree at first is some sort of change captured by the verb 'metabibazomenoi'. Wood's translation renders this verb as "to change minds", option Smith (1997) and Inwood \& Woolf (2013) subscribe to.

In this way, it turns out that people would end up agreeing with what Aristotle says because they have their own conception of happiness which contains something of the truth about this subject. Presumably, these conceptions of happiness are the same as those relevant opinions referred to at the beginning of T1. If this is correct, then what is at stake is that happiness is in some way correctly said to be the greatest good to humans, and that it consists of a life of virtue, wisdom or pleasure. These opinions are the departure of the proof Aristotle seeks to offer.

Now, what does this change of minds and the clarification process of opinions have so as they should be taken as dialectic? Again, by itself, T1 does not supply us with neat evidence. They are taken as dialectical procedures only if some evidence is brought up from EN and Top.

As shown above, EE's methodological passage hangs on an assumption which rest on Top I 2, where dialectic is said to perform exams of endoxa. This exam would 
have as its outcome the change of minds of those people who hold the initial set of endoxa concerning happiness. The occurrence of the rare verb 'metabibazein' in Aristotle's work is used as evidence for a dialectical construal of T1. In addition to this occurrence in T1, this verb appears only in two other passages in Aristotle's work, both in the Topics. The first passage is also found in Top. I 2, and reads like this:

T4: And it is useful in relation to encounters because, once we have reckoned up the opinions of the public, we shall speak to them, not from the beliefs of others, but from their own beliefs, changing their minds ( $\left.\mu \varepsilon \tau \alpha \beta \_\beta \dot{\alpha} \zeta o v \tau \varepsilon \varsigma\right)$ about anything they may seem to us not to have stated well. (Top. I 2 101a30-b34)

This passage has some interpretative difficulties of its own, as, for example, what kind of event instantiate the encounters. For my interests here, I do not need to scrutinize this passage. As for the encounters, I will take them as broadly referring to some sort of debate which is not under the constrains Aristotle provides for some sort of debates in Top. VIII. Thus conceived, an encounter would be an event where some interlocutor skilled in dialectical debate meets one or some people which have not been instructed in this kind of dialectical debate. In this event, the dialectical educated partner would proceed an exam of her interlocutor's opinion such as she would be capable of showing that the set of opinions held by her interlocutor has at least one opinion not well stated. By showing this problem in the set of opinions held by her interlocutor, the dialectical educated partner would make the occasion for her interlocutor to change her mind about the

\section{archai蒡}

no 20 , may-aug. 2017

Fernando Mendonça,

'Does Aristotle have a dialectical attitude in EE I 6? A negative answer', p. 161-190 


\section{archai圈}

n 20 , may-aug. 2017

Fernando Mendonça, 'Does Aristotle have a dialectical attitude in swer', p. 161-190 EE I 6? A negative an-

problematic opinion(s). Then, dialectic would be used without the stricter constrains of the regulated debate displayed in Top. VIII and would have a much broader range of application, producing to other people the occasion for their change of minds. Moreover, there is a dialectical way for changing minds, according to Top. VIII 11 161a30-36 ${ }^{14}$, opposed to the contentious way.

Now, our dialectical interpreter would propose reading $\mathrm{T} 1$ and $\mathrm{T} 4$ together as the latter providing support for the former. Then, she might claim that what is at stake in T1 is a straightforwardly hands-on application of the dialectical procedure laid out in T4. Accordingly, Aristotle would, then, be taken as saying that the method in T1 is a program for the exam of the relevant endoxa presented in the preceding chapters of EE I 6. These endoxa, having been said to be true, but not clear ${ }^{15}$, what would amount to 'not to have stated well' in T4's line 33, would emerge significantly clearer as the outcome of dialectical procedure. The not well-stated opinion would convey some part of the truth, but its language is supposedly misleading.

If T1 and T4 get support from T2, our dialectical interpreter can propose the following picture: she takes phainomena in $\mathrm{T} 1$ and $\mathrm{T} 2$ as meaning endoxa, and those endoxa are true propositions with some kind of problem in their language, so that they are unclear or not well-stated, and Aristotle's procedure is taken as a conceptual analysis which will deliver the same endoxa, or, at least, the most authoritative of them, in much clearer propositions. Having this set of endoxa clarified, the proponents of these endoxa will change their minds as the result of the procedure this conceptual analysis consists of. 
My challenging points

The kind of dialectical construal I have presented above was very influential, but it is being critically discussed nowadays. For instance, D. Frede (2012) discussed the endoxic method, as she named, following Kraut (2006), the method displayed in T2, and concludes that the method in T2 is not a methodological pattern Aristotle uses often. She says:

The explanation of why the endoxic method as deployed in EN 7. 1-2 is rarely used in Aristotle does not mean to suggest that its rarity is due to the fact that he does not encounter confusions concerning central conceptions elsewhere. Aristotle could have used such a method of clarification, and in fact may have employed it for himself wherever he encountered problems of comparable complexity. But, as a matter of fact, in his texts as far as we have them, most of the time he prefers to present his own well-worked-out points of view without a detour via a list of 'reputable views' and the problems involved in them. (FREDE, 2012, p.211-212)

She also notes that the frequent usage of expressions like 'it appears', 'it seems' or 'it is plausible' by Aristotle rests on a common usage of cautionary language in philosophy rather than some specific feature of Aristotelian philosophy appealing to widely shared opinions (Frede, 2012, p.213). Another recent and noteworthy paper questioning dialectical reading of one of the texts we are dealing with here, namely, our T1, is Karbowski's (2015), where he, quite compellingly, shows that in the EE I 6 - II 1 phainomena are not restricted to endoxa and that in this set of chapters, the examples assumed as phainomena play quite a different argumentative role:

\section{archai圈}

no 20 , may-aug. 2017

Fernando Mendonça,

'Does Aristotle have a dialectical attitude in EE I 6? A negative answer', p. 161-190 


\section{archai圈}

no 20, may-aug. 2017

Fernando Mendonça, 'Does Aristotle have a dialectical attitude in swer', p. 161-190 EE I 6? A negative an-

they are the basis for Aristotle to illustrate or obtain evidence for premises of his argument (Karbowski, 2015, p.215-216), which is essentially deductive, and not a kind of conceptual analysis. He says:

This essential aporetic slant to the endoxic method [displayed in EN VII 1] constitutes another substantial difference between it and the Eudemian method. In contrast to the former method, puzzle-raising is not an integral part of the latter method. The Eudemian method is essentially deductive; it arrives at its 'clearer' definitions of ethical subjects by constructing deductive arguments, using the phainomena as witnesses and examples for its premisses, not by raising and solving puzzles. Aristotle never says that clarity about happiness must be reached by means of puzzles in EE I.6; the word 'puzzle' (aporia) or the corresponding verb is not even mentioned in that chapter. (KARBOWSKI, 2015, p.217).

Karbowski's paper thoroughly covers the application of the method displayed in T1 in the following chapters of EE, namely, I7- II1. His strategy is to show that Aristotle deploys in these chapters arguments that can hardly be considered as dialectic. My claim is similar: I intend to show that EE I 6 does not propose a dialectical program as well, but I want to focus on undermining the assumptions I enumerate above and showing that the EE I 6's previous chapters do not envisage endoxa as some sort of propositions badly stated and, thus, unclear, which will emerge clear after a dialectical exam. Rather, those endoxa are seen as definitely insufficient for a definition of happiness on the basis of empirical arguments, hence, the reason why Aristotle is not bound by a sort of conceptual analysis. 
The first assumption described above identifies 'phainomena' with 'endoxa', if not in every possible occurrence of these terms, at least it does that in $\mathrm{T} 1$ and T2. I agree with Karbowski (2015) indicating that endoxa is only part of the material used as phainomena in the following chapters of $E E$ I 6 . In those chapters, Aristotle is happy to deploy, as it were, inductive argument which does not lie on endoxa, for instance, when he concludes that from some empirical evidence that some things like cloak, boat and house each have its own function, then the soul also has its own function (EE II 1 1218b37-1219a5). This argumentative pattern is far different from the conceptual analysis vindicated in T2, according to the dialectical interpreter, and proposed to be a model for the program set in $\mathrm{T} 1$.

Now, it is reasonable to concede that, in some contexts, Aristotle is willing to accept that some phainomena are endoxa. It is also reasonable to concede that A2 is, in fact, true: there is at least one endoxon at stake in T1. A quick look at $E E$ I 1-5 gives us opinions shared by wise men, like that happiness consists of pleasure, virtue or wisdom (e.g. EE I 1 1214a30-33), which are easily agreed to be endoxa. But does Aristotle hold some dialectical attitude toward them? That is, is Aristotle willing to save the phainomena/endoxa by conceptual analysis in the way the dialectical interpreters understand $\mathrm{T} 2$ to be prescribing?

A closer look to EE I 1-5 might give us some clues about how Aristotle deals with those opinions which might be reasonably taken as endoxa. As mentioned above, Aristotle does not count every opinion equally as endoxa. About happiness, everybody thinks of themselves as capable of opining on this subject.

\section{archai圈}

no 20, may-aug. 2017

Fernando Mendonça, 'Does Aristotle have a dialectical attitude in $E E$ I 6? A negative answer', p. 161-190 


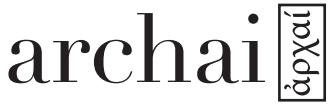

no 20, may-aug. 2017

Fernando Mendonça, 'Does Aristotle have a dialectical attitude in EE I 6? A negative answer', p. 161-190

\section{6}

Aristotle, however, is clear: "Similarly, neither need we examine the views of the many; they speak in an unreflective way on almost any topic, most of all when they speak about this; only the opinions of the wise on this subject at least - should be examined." (cf. EE I 3 1214b34-1215a2 - emphasis is mine). EE seems to have a much stricter attitude towards accepting an opinion as relevant than the attitude in the Topics towards assuming relevant endoxa for the dialectical debate. This difference is quite important and should not be overlooked. It represents a problem for the dialectical interpreter as the sentence which presents endoxa in Top. I 1 100b 21-23 makes undoubtedly clear that the opinions of most people do count in dialectical argumentation ${ }^{16}$.

Furthermore, and more importantly, Aristotle does not show in EE I 1-5 the attitude towards relevant opinions expected in a dialectical construal of T1 as following the conceptual analysis program of T2. In the same manner as in the $E N$, in the $E E$ (I 2 1214b11-17) Aristotle assumes that happiness means a good life directed toward and organized by an ultimate goal ${ }^{17}$. The enquiry Aristotle undertakes seeks to narrow down this assumption in order to get a better understanding of what happiness is and what it consists of.

There are some opinions about what happiness consists of which are present throughout EE 1-5. These opinions hold happiness as a life organized either by pleasure, or virtue, or wisdom, or a blend of them. For Aristotle, what is controversial is not whether a happy life has or might have pleasure, virtue or wisdom, or all of them in some proportion. Rather, the controversy 
is whether they are what happiness consists of, since it is not enough for something to be considered happiness to be a sine qua non condition for happiness ( $E E$ I 2 1214b 15-27). So, on the one hand, we have a set of opinions which holds pleasure, wisdom or virtue as what constitute happiness, on the other hand, Aristotle wants to investigate if wisdom, virtue and pleasure are merely necessary conditions for happiness, since $\mathrm{x}$ being a necessary condition for something does not mean that this thing consists of $\mathrm{x}$. Aristotle gives as an example that breathing is a necessary condition of any good or bad that happens to us, since no good or bad would affect us if we could not breath. Notwithstanding, we would not say that breathing plays any major role in being good or bad, even less, would we say that it constitutes being good or bad (1214b19-22).

Having set up this picture, Aristotle says: "It is these opinions, then, that it is right for us to investigate; for the refutation of those who dispute a certain position is a demonstration of the opposing view." (I 3 1215a57). What opinions are these? The context gives us that these opinions are the ones wise men hold. Considering that Aristotle dismisses the opinions of the many, and truly examines the opinions that happiness consists of pleasure, or wisdom, or virtue, these are the right opinions to investigate on the aporiai concerning the best life (1215a 3-5). Now, we have Aristotle mentioning in the same context both opinions or endoxa and an investigation which proceeds through aporiai, suggesting that the problem is solved when some opinion is refuted. Given the dialectical interpretation of T1 and T2, wouldn't we be in front of a dialectical procedure ${ }^{18}$ ? It appears that we have important similarities between what Aristotle says in EE

\section{archai蒡}

no 20, may-aug. 2017

Fernando Mendonça, 'Does Aristotle have a dialectical attitude in $E E$ I 6? A negative answer', p. 161-190 


\section{archai圈}

no 20, may-aug. 2017

Fernando Mendonça, 'Does Aristotle have a dialectical attitude in EE I 6? A negative answer', p. 161-190

\section{8}

I 3 and what he says in T1 and T2 (according to the dialectical interpreter).

I do not think that these appearances are true, though. Firstly, it seems to me quite unlikely that Aristotle were saying that the refutation of any of the three opinions about what constitutes happiness is the demonstration of the opposing view of each of these opinions, and is also unlikely he were proposing that the refutation of one or two of these opinions is the demonstration of the remaining. Aristotle is not willing to refute that pleasure, wisdom or virtue are necessary conditions to happiness or constitute happiness and, then, to propose their opposing states or affections as playing these roles. As a matter of fact, pleasure, wisdom and virtue will be part of Aristotle's enquiry until he gets the definition of happiness in $E E$ II 1. On the other hand, it is unlikely that Aristotle were proposing that the refutation of one or two of those opinions are the demonstration of the remaining. The refutation of the opinions according to which happiness is virtue or pleasure does not entail that it is wisdom, and mutatis mutandis the same conclusion obtains for all combination of opinions refuted. So, this procedure simply does not go through without a complementary premise guaranteeing that there are these three opinions and only these three. But there is no clue for thinking that it is what Aristotle is committed to here.

It seems much more likely that Aristotle is examining not each one of those opinions, but the aporia he raises concerning their being mere necessary conditions to happiness or their being what happiness consists of. If this is so, we have what Aristotle wanted in 
the first place, that is, an aporia in which the refutation of one side is the demonstration of the other side. So, if Aristotle is seeking the definition of happiness, then he will need to find what constitutes happiness essentially, and not merely its necessary conditions. He has assumed that pleasure, wisdom and virtue have good credentials as part of the happy life. What Aristotle needs to find out is whether their presence is what makes one's life happy. If he gets a negative answer, then he will have demonstrated that they are no more than important necessary conditions.

Aristotle proceeds a quick exam of these opinions in $E E$ I 5 . He firstly remarks that some lives, despite being full of pleasures, would not be held as the best lives ${ }^{19}$. He goes as far as to say that non-existence is preferable to some lives dedicated to pleasures that are not good at all (I 5 1215b25-26). If there are lives dedicated to pleasure which are not good lives, and happiness is the best life, then pleasure is not what happiness consists of.

As for virtue, Aristotle remarks a fact to refute the opinion that virtue constitutes the best life. Some people honestly live a virtuous life, but some, like most politicians, seek reputation by acting virtuously. Their goal is not, then, to be virtuous, but to earn money or personal advantages (EE I 5 1216a 19-27). This is enough for Aristotle to conclude that a life of virtue might not be happy, since virtue might not be an end in itself.

About wisdom, Aristotle carries out a similar procedure. In 1216b15-25, Aristotle says that the elder Socrates thought that the end (telos) is the knowledge

\section{archai葶}

no 20, may-aug. 2017

Fernando Mendonça, 'Does Aristotle have a dialectical attitude in EE I 6? A negative answer', p. 161-190 


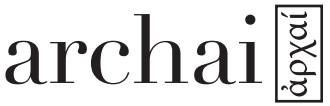

no 20, may-aug. 2017

Fernando Mendonça, 'Does Aristotle have a dialectical attitude in EE I 6? A negative answer', p. 161-190 of virtue, hence, why he asked for the definition of the specific virtues. Accordingly, in the same way as one becomes a geometer or a builder when she learns geometry or building, one would be virtuous inasmuch as she knows virtue. Aristotle, however, does not find this approach fits the demands of productive sciences on the basis that, despite valuable knowledge, the knowledge of virtue is not what he aims at, but how to be happy. So, someone might know what virtue is and nonetheless not be virtuous. It seems that Aristotle's point is that knowledge of ethical matters is highly regarded, but this is not what he is searching. He wants an account of happiness which enables one to be happy ${ }^{20}$. Then, he seeks an account of happiness which makes clear what it is and what it consists of, being that the goal of the enquiry Aristotle undertakes in the $E E^{21}$.

If this is right, Aristotle has shown that pleasure, wisdom and virtue simpliciter are not the end which makes life happy. They might and they do play a major role in a happy life but they are not what happiness is or consists of. None of the arguments he deploys, and this is important for my goal, are based on any kind conceptual analysis. There is no conceptual confusion to be dealt with, or obscure language to be clarified in any of the opinions analysed. Arguably, Aristotle carries out the refutation of happiness consisting in virtue, wisdom or pleasure on the basis of empirical facts used as instances which contradict the relevant opinions. Then, Aristotle does not show the attitude expected for a dialectical treatment based on conceptual analysis of endoxa. Aristotle does not regard the opinions he analyses as though they had true propositional content but were poorly formulated. To the contrary, Aristotle's preliminary approach to them shows that 
they cannot account alone for what conduces to happiness. Once this is obtained, Aristotle has what he needs to say that those opinions were correctly said but unclearly. By saying that pleasure, or wisdom or virtue leads to happiness, one means that they are alone what make life happy, since they are the goal which organizes one's life. Aristotle showed that these goods alone do not lead to happiness, although they are necessary conditions to happiness. But this is excessively vague and insufficiently informative, despite being true.

Then, until EE I 5, Aristotle has shown that happiness is the best life, oriented towards a goal which organizes one's life, and that virtue, pleasure and wisdom are solidly regarded as necessary conditions to happiness. This long argument, which starts in the very first chapter of the EE, supplies Aristotle with something to investigate upon, that is, an explanandum. What he obtained by solving the EE I 3 aporia is that wisdom, virtue and pleasure belong to happiness. More accurately, he obtained that wisdom, virtue and pleasure belong to happiness as necessary conditions for it. Having this, Aristotle has something to enquire upon, that is, as he himself says in T1 (iv), something from which demonstration is possible. Aristotle, now, has to demonstrate the cause why wisdom, pleasure and virtue belong to happiness. Now, to investigate and to show the real cause (to dia $t i$ ) of something having certain properties mark off the boundaries of philosophical (and scientific) enquiry (1216b35-40). The philosopher, seeking the cause, must rely ultimately on phainomena. Consistent arguments are not the decisive criteria to the ascription of truth-value to a proposition displayed in a syllogism's conclusion.

\section{archai圈}

no 20, may-aug. 2017

Fernando Mendonça, 'Does Aristotle have a dialectical attitude in $E E$ I 6? A negative answer', p. 161-190 


\section{archai}

no 20, may-aug. 2017

Fernando Mendonça, 'Does Aristotle have a dialectical attitude in EE I 6? A negative answer', p. 161-190
A proposition featured in a syllogism's conclusion might have been deduced by means of false premises and still be true, or yet being deduced by true premises which, however, do not relate to the conclusion as to show the appropriate cause of the conclusion (EE I $61216 \mathrm{~b} 41-1217 \mathrm{a} 10)^{22}$. To wit, the conclusion is true, but not for the cause it is deduced (EE I 6 1217a1417). Consequently, Aristotle seems to be claiming that in most philosophical enquiries, one should proceed on the grounds of making appeal to phainomena understood as non-linguistic facts, since logoi by themselves do not guarantee that the propositions they consist of are true. If this is so, it fits the picture quite well I am proposing here.

Until $E E$ I 6, Aristotle has shown that happiness, in fact, has wisdom, pleasure and virtue as its properties. Aristotle himself acknowledges that it is the case to seek out what exactly is the role that pleasure plays by being part of a happy life (EE I 5 1216a32-37). So, after showing that the Platonic Good and the common good are not achieved by action (EE I 7-8) ${ }^{23}$, Aristotle brings back these properties to discussion. But, this time, he is concerned with approaching them as being in the soul, and this procedure is completely strange to the original opinions Aristotle departed from. At the beginning of $E E$ they were taken as constituting happiness, and nothing was said about them being in the soul. This change in the argument can be understood within my interpretation, since Aristotle's concern is now to show why wisdom, pleasure and virtue belong to happiness. Due to our construal of the exam of opinions from I 1-6, neither the aporia in I 3, nor the procedure in $\mathrm{T} 1$ seems to be in accordance with the dialectical construal of them. I shall now turn to A3. 
A1, by itself, is not sufficient for one to claim that where 'phainomena' and 'endoxa' may be identified as denoting the same set of propositions, then this context is dialectical. Even if A1 is true, what I think, considering Karbowski (2015), it is not, it needs A3, since A3 might guarantee that endoxa are the domain of dialectic and dialectic only. The evidence for A3, however, is not compelling. In the Topics Aristotle does not confine endoxa within the boundaries of dia${ }^{\text {lectic }}{ }^{24}$. Then, having endoxa as premises of dialectical syllogism does not entail that only dialectical syllogisms use endoxa. Furthermore, another argumentative discipline conspicuously relies on endoxa, namely, the rhetoric ${ }^{25}$. So, why do interpreters tend to identify arguments relying on endoxa as dialectical instead of rhetorical ${ }^{26}$ ? My point is that there is no good prima facie reason to ascribe dialectical characteristics to an argument only because it relies on endoxa $a^{27}$.

As it was stated above, a dialectical interpreter might agree with what I have just said about A3 and yet keep that $\mathrm{T} 1$ is dialectical because it proceeds in accordance with T2, whose method is dialectical. But this is now very problematic since Aristotle does not seem to have the same attitude towards endoxa in $\mathrm{T} 1$ as he allegedly had in T2. Then, the dialectic interpreter does not get any evidence either from $\mathrm{A} 3$ or from $\mathrm{T} 2$.

A4 assumes that dialectic is a method of enquiry which consists of examining endoxa. It is true that dialectic examines endoxa, but it needs some qualification regarding it being a method of enquiry. It goes without saying that Aristotle wants to find, in the Topics, a method that enables one to argue through syllogisms about any matter and say nothing

\section{archai圈}

no 20, may-aug. 2017

Fernando Mendonça, 'Does Aristotle have a dialectical attitude in $E E$ I 6? A negative answer', p. 161-190 


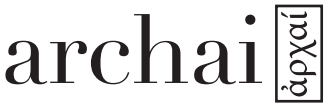

no 20, may-aug. 2017

Fernando Mendonça, 'Does Aristotle have a dialectical attitude in EE I 6? A negative answer', p. 161-190 inconsistent when she is put under questioning (Top. I 1 100a 18-24). In order to accomplish what he wants, Aristotle needs to clarify what a syllogism is and to develop a set of argumentative skills which involves a theory of predication, some logical principles and argumentative tools (e.g. discovering premises, testing homonymy, finding differences, and investigating similarities ${ }^{28}$ ). If one knows them, one will be much better equipped to deal with several fields where argumentative skills are required than someone who has no or little experience in arguing. This situation is pretty much the same as when one, who has been educated in playing cello, starts to learn violin. She will be much better equipped to learn violin than someone who has never played any musical instrument. I think this is the case in Topics I 2, when Aristotle says that the treatise, not dialectic, is important to note (Top. I 2 101a25-26), is useful for the exercises, encounters and philosophical sciences. If this is right, Aristotle is saying that the set of skills dealt with in the Top$i c s$ in order to equip someone to undertake a dialectical debate is also useful in other domains, philosophy included. In the same way as we would avoid saying that someone who can play cello, plays cello when is playing violin while using some common skill learned from her violin lessons, we should avoid saying that someone skilled in dialectic is doing dialectic when using argumentative skills common both to dialectic and philosophy while doing philosophy. In addition, it is not clear what a dialectical interpreter understands by 'method of enquiry'. It is not an easy and a simple task to find in the Topics something like a number of articulate rules on how to proceed to investigate and produce knowledge about a subject-matter. Even if it is possible to say that Top. I 2 clearly states that 
dialectic has the ability to examine, as we see in T3, and, then, dialectic is some sort of method, this ability is useful in relation to discovering or stablishing the first principles of sciences. In T1, as well as in T2, there is no principle being discovered or proven by the program there stated.

Finally, A5 assumes that dialectic is useful at least as it can produce agreement, as it is capable of making someone change her own mind. This assumption strongly relies on the verb 'metabibazomenoi', in T1's line 30 , rendered as 'to change minds'. There is ground to question whether this translation is the most adequate one ${ }^{29}$. In fact, we do not find 'to change minds' as one of the meanings of this verb in Liddele $r$ Scott; in this dictionary, we find 'change the course of the argument' instead. I don't need to go deeper into this ${ }^{30}$. All I need is to highlight that the crucial passage in the Topics where Aristotle mentions this kind of change captured by this verb, namely Top. I 2 101a 30-34, is ruled by the utilities of the treatise, not dialectic, regarding the encounters. As I mentioned beforehand, the Topics are useful for different argumentative disciplines, since it deals with some logical and linguistic skills which are not confined within the boundaries of dialectic. So, even if we were sure Aristotle was using the skills and tools he elaborates in the Topics, we should not say that it is sufficient to make $\mathrm{T} 1$ dialectical.

If my construal is sound, Aristotle is not showing a dialectical attitude towards endoxa as it was expected in dialectic understood as conceptual analysis, and many assumptions the dialectical interpreter needs simply do not go through due to lack of evidence. My criticism of A1, A3, A4 and A5 is not limited to their

\section{$\operatorname{archai}$ 苃}

no 20, may-aug. 2017

Fernando Mendonça, 'Does Aristotle have a dialectical attitude in EE I 6? A negative answer', p. 161-190 


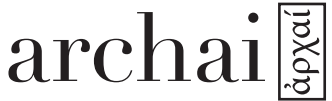

no 20, may-aug. 2017

Fernando Mendonça, 'Does Aristotle have a dialectical attitude in EE I 6? A negative answer', p. 161-190 role in T1, as it can be applied to any case of enquiry taken as dialectical. As for A2, I am prone to affirm that similar result is obtained if we carry out a close scrutiny of many of the allegedly dialectical arguments in Aristotle's works. I hope that my arguments contribute towards demystifying Aristotle's conception of dialectic and his appeal to shared opinions, avoiding an over-biased construal of dialectic as a powerful method for philosophy that operates by saving phainomena/endoxa ${ }^{31}$.

\section{Notes}

1 E.g. Irwin (1988), Bolton (1990), Ward (2008), Kraut (2006) and many others. I call this a revival because it gave dialectic a new strength if compared to some positions held by interpreters who, like Ross (1995), considered dialectic in quite a derogatory way.

2 I will use the following abbreviations of Aristotle's works: 'Top' for 'Topics', 'EE' for 'Eudemian Ethics', and 'EN' for 'Nicomachean Ethics'.

3 By 'method of enquiry' I mean an articulated body of procedures which direct an investigation of a certain sort.

4 All quotations of the Topics are from Smith's (1997) translation.

5 Bostock (2000, p.215) says that this text sets out a method which might be fairly called 'pure dialectic'.

6 All quotations of the $E E$ are from Woods (1992).

7 Bostock describes dialectical procedure of conceptual analysis along these lines: "The method set out in VII.1 we may call the method of 'pure dialectic' When made fully explicit, it begins by stating what the relevant opinions are, and then stating what puzzles they give rise to. Subsequent discussion then aims to resolve these puzzles, and I shall understand the discussion as 'purely dialectical' if the only technique employed is that of drawing distinctions which allow the needed qualifications to he introduced, 
so that the appearance of contradiction is dispelled. It may fairly be said that the discussion of akrasia in VII.1-10 illustrates this method very nicely." (BOSTOCK, 2000, p.215-216 - emphasis is mine)

8 As my focus here is to challenge dialectical readings of T1, especially the one which consists in conceptual analysis, I will, for the sake of my argument, treat T2 as proposing a dialectical program of conceptual analysis. It does not mean that I committed to an interpretation which takes $\mathrm{T} 2$ as in fact proposing such a program. I have dedicated myself to explain Aristotle's conception of dialectic in Mendonça (2015).

9 See Owen (1986).

10 All quotations of the $E N$ is from Rowe and Broadie (2002)

11 For instance: Ward (2008), Smith (1997) Irwin (1988)

12 I will consider only the opinions Aristotle mentions before EE I 6, but I acknowledge that the program Aristotle displays in 11 also applies to the opinions Aristotle refutes in EE I 7-8.

13 Ward (2008, p.47), for example, resorts to this move.

14 Aristotle says in the third passage where the mentioned verb appears: "For nothing prevents things that are not so from seeming more so to someone than the truth, so that if the argument comes about from what seems so to him he will more likely be convinced or benefited. And anyone who is to change minds $[\mu \varepsilon \tau \alpha \beta \iota \dot{\alpha} \zeta o v \tau \alpha]$ well must change $[\mu \varepsilon \tau \alpha \beta \iota \beta \dot{\alpha} \zeta \varepsilon v v]$ them dialectically, not contentiously - as the geometer must do so geometrically - no matter whether the conclusion be false or true." (Top. VIII 11 161a30-36)"

15 See Lesher (2010) for an account of what 'saphēneia' means.

16 It is particularly a difficult problem for those interpreters who understand Aristotle to be proposing, as it were, degrees of endoxicality according to the acceptability of an opinion, that is, the more acceptable/accepted is an opinion, the more endoxical is its status (for an interpretation of this kind, see Bolton (1990)). If it is so, why does Aristotle dismiss the opinions held by most people as being irrelevant to ethical enquiry and, eventually, to any kind of enquiry?

\section{archai蒡}

n 20, may-aug. 2017

Fernando Mendonça,

'Does Aristotle have a dialectical attitude in $E E$ I 6? A negative answer', p. 161-190 


\section{archai圈}

no 20, may-aug. 2017

Fernando Mendonça, 'Does Aristotle have a dialectical attitude in EE I 6? A negative answer', p. 161-190
17 As Aristotle says in the EN I 4 1095a14-22, everybody agrees with this assumption however very general and insufficiently informative it is.

18 For interpreters who have defended this position, see, e.g. Cooper (2009), Zingano (2007).

19 EE I 5 1215b30-1216a10.

20 "If something is fine, understanding it is fine also; but still, in the case of virtue, the most valuable thing is not to have knowledge of it, but to know from what sources it arises. For what we wish is to be courageous, not to know what courage is; to be just, not to know what justice is; in the same way as (we wish) to be healthy rather than to know what being healthy is, and to be in a good state, rather than to know what it is to be in a good state." (EE I 5 1216b 19-25)

21 "But first we must consider what living well consists in and how it is to be attained" (EE I 1 1214a14-15).

22 Deducing true conclusions from true premises which do not display the adequate cause of the conclusion was one procedure used by sophists. See Angioni (2012) for accurate account of this kind of sophistic argument.

23 A good account of the relation between EE I 1-6 and the EE I 7-8 is found in Zillig (2014).

24 See: Top. I 1 100a 18-21; 100a29-30, b21-23.

25 See, e.g., Rhetoric I 2 1356b28-35.

26 Zillig (2014) shows some rhetorical features in EE I 1-6, even if his paper's goal is not to cash out rhetorical aspects of $E E$.

27 I have dedicated to a long exam of this subject in Mendonça $(2014,2015)$.

28 Aristotle presents and elaborates on these tools along chapters 13-16 in Top. I

29 See an alternative translation in Kenny (2011)

30 In Mendonça (2015) I have elaborate on this matter.

31 I am deeply indebted to Lucas Angioni and Raphael Zillig for having organized conferences (in Campinas and Porto Alegre) where I could discuss earlier versions of this paper, and 
for having discussed the method of $E E$ I 6 with me many times. I am also indebted for many comments and questions I received from Felipe Weinmann, Wellington Almeida, Breno Zuppolinni, Daniel Nascimento, David Ebrey, and Ben Morisson. Last but not least, I am indebted to Christina Kane for having read a previous version of this text.

\section{BIBLIOGRAPHY}

ANGIONI, L. (2012). Três tipos de argumento sofístico. Dissertatio, v.36, p.187-220

BOLTON, R. (1990). The epistemological basis of Aristotelian dialectic. In: DEVEREUX, D.; PELLEGRIN, P. (eds.). Biologie, Logique et Métaphysique chez Aristote. Paris, Éditions du CNRS, p.185-236

BOSTOCK, D. (2000). Aristotle's Ethics. Oxford, Oxford University Press

COOPER, J. M. (2009). Nicomachean Ethics VII. 1-2: Introduction, Method, Puzzles. In: NATALI, C. (ed.). Aristotle's Nicomachean Ethics, Book VII. Oxford, Oxford University Press

FREDE, D. (2012). Endoxon Mistique. Oxford Studies in Ancient Philosophy 43. p.185-215

INWOOD, B.; WOOLF, R. (2013). Aristotle: Eudemian Ethics. Cambridge, Cambridge University Press.

IRWIN, T. H. (1988). Aristotle's First Principles. Oxford, Clarendon Press

KENNY, A. (2011). Aristotle The Eudemian Ethics. Oxford, Oxford University Press

KARBOWSKI, J. (2015). Phainomena as Witnesses and Examples: The Methodology of Eudemian Ethics 1.6. Oxford Studies in Ancient Philosophy 49. p 193-226

KRAUT, R. (2006). The Blackwell Guide to Aristotle's Nicomachean Ethics. Oxford, OUP https://doi. org/10.1002/9780470776513

LESHER, J. H. (2010). Saphêneia in Aristotle: Clarity, Precision and Knowledge. Apeiron 43, p.143-156. https://doi. org/10.1515/apeiron.2010.43.4.143

\section{archai圈}

no 20, may-aug. 2017

Fernando Mendonça,

'Does Aristotle have a dialectical attitude in EE I 6? A negative answer', p. 161-190 


\section{$\operatorname{archai}$}

no 20, may-aug. 2017
Fernando Mendonça, 'Does Aristotle have a dialectical attitude in EE I 6? A negative answer', p. 161-190
LIDDELL, H. G.; SCOTT, R. (1996). Greek-English Lexicon: with a revised supplement. Oxford, Oxford University Press

MENDONÇA, F. M. (2014). A utilidade dos Tópicos em relação aos princípios das ciências. In: ANGIONI, L. (ed.). Lógica e Ciência em Aristóteles. Campinas, Editora PHI

MENDONÇA, F. M. (2015). Os Tópicos e a Competência Dialética: Lógica e Linguagem na Codificação do Debate Dialético (Tese de Doutorado). Campinas, Universidade Estadual de Campinas

OWEN, G. E. L. (1986). Tithenai ta phainomena. In: NUSSBAUM, M. C. (ed.). Logic, Science and Dialectic. New York, Cornell University Press, p.239-251

ROBERTS, W. R. (1991). Aristotle's Rhetoric. In: BARNES, J. (ed.). The complete works of Aristotle. Princeton, Princeton University Press

ROSS, W, D. (1995). Aristotle. 6ed. London and New York, Routledge

ROWE, C.; BROADIE, S. (2002). Aristotle's Nicomachean Ethics. Oxford, Oxford University Press

SMITH, R. (1997). Aristotle's Topics: Books I and VIII with excerpts from related texts. Oxford, Clarendon Press

WARD, J. (2008). Aristotle on Homonymy: Dialectic and Science. Cambridge, Cambridge University Press

WOODS, M. (1992). Aristotle Eudemian Ethics. Oxford, Clarendon Press

ZILLIG, R. (2014). As relações entre o proêmio da Ética Eudêmia e restante da obra: uma discussão a partir da análise de Ética Eudêmia I.7. Philósophos 19, n.2, p.221-243

ZINGANO, M. (2007). Aristotle and the Problems of Method in Ethics. Oxford Studies in Ancient Philosophy 32, p.297-330

Submitted in August an accepted for publication in October, 2016 